\title{
Agronomic Traits and Fatty Acid Composition of High-Oleic Acid Cultivar Hosim
}

\author{
Jeong-Dong Lee ${ }^{1,2} *$, Minsu Kim ${ }^{1}$, Krishnanand P. Kulkami ${ }^{1}$, Jong Tae Song ${ }^{1,2}$ \\ ${ }^{1}$ School of Applied Biosciences, Kyungpook National University, Daegu 41566, Korea \\ ${ }^{2}$ Institute of Agricultural Science \& Technology, Kyungpook National University, Daegu 41566, Korea
}

\begin{abstract}
The soybean [Glycine max (L.) Merr.] cultivar 'Hosim' (registration number: 5989, registration date: April 8, 2016) was developed at Kyungpook National University, Republic of Korea. Hosim was registered as a cultivar after a two-year (2014-2015) analysis by the Korea Seed \& Variety Service, Republic of Korea. It is an $\mathrm{F}_{4}$ plant selection composited in the $\mathrm{F}_{5}$ generation developed from the $17 \mathrm{D} \times \mathrm{S} 08-14788$ cross. Hosim is a productive, mid-maturing ( $\sim 130$ days $)$ soybean cultivar with white flowers, tawny pubescence, determinate growth, and yellow seed coat with gray hila. The yield of Hosim was $3.5 \mathrm{t} / \mathrm{ha}$, which was similar to those of the control cultivars, 'Uram' and 'Taekwang'. Hosim soybean oil contained $\sim 79 \%$ oleic acid. Hosim could be highly useful in producing high-quality soybean oil, and preparing soy-based foods with high oleic acid concentration.
\end{abstract}

Keywords Soybean, Fatty acid, High oleic acid

\section{INTRODUCTION}

Soybean [Glycine $\max (\mathrm{L}$.$) Merr.] is an important source$ of vegetable oil worldwide. Typically, oil from cultivated soybean contains $12 \%$ palmitic, $4 \%$ stearic, $23 \%$ oleic, $53 \%$ linoleic, and 8\% linolenic acids (Wilson 2004). The composition and distribution of fatty acids are important for determining the quality of soybean oil (Lee et al. 2007). Oleic acid has been reported to have positive effects on human health, such as reduction of total and low-density lipoprotein cholesterol and triacylglycerol levels in plasma, and prevention of atherosclerosis (Teres et al. 2008; Bahrami 2009). The dietary intake of functional foods with high oleic acid concentrations can reduce the risk of cardiovascular disease in humans (Williams 2001). Diets rich in oleic acid may similarly have positive effects on inflammatory diseases (Carrillo et al. 2012). It may improve the related immune response, by interfering with the roles of various components of the immune system, such as macrophages, lymphocytes, and neutrophils, resulting in the successful elimination of pathogens such as bacteria and fungi (Sales-Campos et al. 2013). An increase in oleic acid intake may be advantageous, as it limits saturated fat consumption. Additionally, increasing the oleic acid concentration in soybeans through genetic modification could improve the oxidative stability of soybean oil, thereby eliminating the requirement for hydrogenation. Such approaches constitute an economical and efficient method for improving oil quality (Ascherio and Willett 1997; Lee et al. 2007).

Different genetic backgrounds and genetic resources responsible for elevated oleic acid concentrations have been developed by several researchers (Wilson et al. 1981; Rahman et al. 1994; Burton et al. 2006; Monteros et al. 2008; Dierking and Bilyeu 2009; Hoshino et al. 2010; Pham et al. 2010; Pham et al. 2011). Recently, two research

Received January 24, 2018; Revised January 30, 2018; Accepted January 30, 2018; Published March 1, 2018

*Corresponding author Jeong-Dong Lee, jdlee@knu.ac.kr, Tel: +82-53-950-5709, Fax: +82-53-958-6880 
groups independently reported that soybeans with $\sim 80 \%$ oleic acid could be developed by combining mutant alleles at the FAD2-1A locus (Glyma10g42470) with mutant alleles at the FAD2-1B locus (Glyma20g24530) (Hoshino et al. 2010; Pham et al. 2010; Pham et al. 2011). In the recent past, several researchers have studied the effects of high-oleic acid traits, developed by combining mutant alleles at the FAD2-1A locus with mutant alleles at the $F A D 2-1 B$ locus, on seed yield, and reported that the high-oleic acid phenotype has no negative effects on yield (Hoshino et al. 2010; La et al. 2014; Kim et al. 2015). These findings encourage breeders to employ measures for substantially increasing the oleic acid concentration in soybean varieties. To date, there is no report on the development of high-oleic acid soybean cultivars achieved by combining the two mutant allele sets. We developed a soybean cultivar with high oleic acid concentration, and in this study, we evaluated the agronomic traits of the high-oleic acid cultivar Hosim to provide information about this cultivar for commercial use.

\section{MATERIALS AND METHODS}

\section{Parental lines and pedigree information}

Hosim (breeding line JD11-0070) originated from the 17D $\times$ S08-14788 cross (Fig. 1). The line 17D, whose oil contains $35 \%$ oleic acid, was developed by ethyl methanesulfonate (EMS) mutagenesis of Williams 82, and contains a missense mutation in FAD2-1A (Dierking and Bilyeu 2009). S08-14788, obtained from the Jake $\times$ PI 283327 cross, and contains a missense mutation in FAD2-1B inherited from PI 283327 (Lee et al. 2012). $\mathrm{F}_{2}$ seeds from the 17D $\times$ S08-14788 cross were chipped for analysis of fatty acid composition as described in previous reports (Scherder et al. 2008) in late spring of 2009 . $\mathrm{F}_{2}$ seeds with $\sim 75-80 \%$ oleic acid were sown, and allowed to develop until the $\mathrm{F}_{4}$ generation in a greenhouse of Kyungpook National

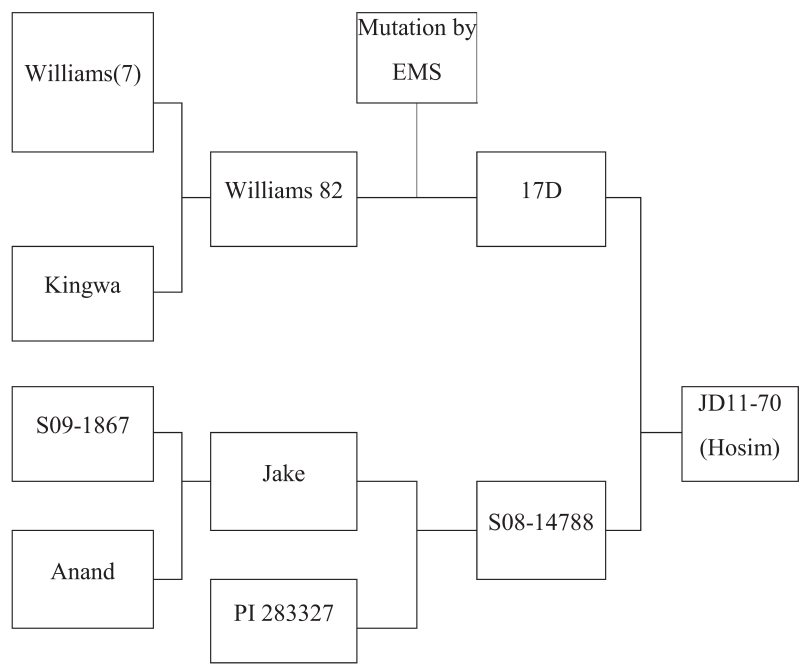

Fig. 1. Pedigree of cultivar 'Hosim' and its ancestors.

\begin{tabular}{|c|c|c|c|c|c|c|c|c|}
\hline Year & 2008 & $\begin{array}{c}2008- \\
2009 \\
\text { winter }\end{array}$ & 2009 & $\begin{array}{c}2009- \\
2010 \\
\text { winter }\end{array}$ & 2010 & 2011 & $2012-2015$ & 2016 \\
\hline \multirow[t]{7}{*}{ Generation } & Crossing & $\mathrm{F}_{1}$ & $\mathrm{~F}_{2}$ & $\mathrm{~F}_{3}$ & $\mathrm{~F}_{4}$ & $\mathrm{~F}_{5}$ & $\mathrm{~F}_{6}-\mathrm{F}_{9}$ & $\mathrm{~F}_{10}$ \\
\hline & 17D & & & 1 & 1 & 1 & \multirow{6}{*}{ Bulk } & \multirow{6}{*}{ Hosim } \\
\hline & & & 2 & 2 & 2 & 2 & & \\
\hline & $x$ & & 3 & 3 & 3 & 3 & & \\
\hline & & & 4 & 4 & 4 & 4 & & \\
\hline & S08-14788 & & 5 & 5 & 5 & 5 & & \\
\hline & & & 6 & 6 & 6 & 6 & & \\
\hline Procedure & & & & \multicolumn{3}{|c|}{ Line selection } & $\begin{array}{l}\text { Preliminary yield test }\left(\mathrm{F}_{6}\right) \text {, } \\
\text { Regional yield test }\left(\mathrm{F}_{7}\right) \text {, and } \\
\text { Variety test byKorea Seed and } \\
\text { Variety Service }\left(\mathrm{F}_{8}-\mathrm{F}_{9}\right)\end{array}$ & \\
\hline
\end{tabular}

Fig. 2. Pedigree diagram of 'Hosim'. 
University, Republic of Korea during the winter of 2009-2010. The pedigree method was used to select and evaluate soybean lines in the $\mathrm{F}_{4}-\mathrm{F}_{5}$ generations during the 2010 and 2011 growing seasons in Korea (Fig. 2).

\section{Yield trials}

Hosim, an $\mathrm{F}_{6}$ high-oleic acid line, and two commercial soybean cultivars, Taekwang and Uram (Ko et al. 2016), were tested in Gunwi, Republic of Korea in 2012. In the subsequent year 2013, Hosim, 'Daewon', and Uram were cultivated at three different locations [Chuncheon $\left(37^{\circ} 52^{\prime} 52.73^{\prime \prime} \mathrm{N}\right.$, $\left.127^{\circ} 43^{\prime} 47.90^{\prime \prime} \mathrm{E}\right)$, Gunwi (36 $\left.6^{\circ} 24.63^{\prime \prime} \mathrm{N}, 128^{\circ} 35^{\prime} 7.47^{\prime \prime} \mathrm{E}\right)$, and Jeongup $\left.\left(35^{\circ} 30^{\prime} 44.99^{\prime \prime} \mathrm{N}, 126^{\circ} 50^{\prime} 1.64^{\prime \prime} \mathrm{E}\right)\right]$ in the Republic of Korea. (Kim et al. 2015). In 2016, Hosim, Taekwang, and Uram were evaluated at Gunwi.

The experiments were performed in a randomized complete block design with three replicates at each location. For each cultivar, seeds were planted in 4-or-3-m-long four-row plots with a spacing of $70 \mathrm{~cm}$ between rows, and hills within the rows were spaced at 15-cm gaps with two seedlings per hill (Kim et al. 2015). The dates of planting in Gunwi were May 27, 2012, June 13, 2013, and June 9, 2016. The dates of planting were May 26 in Chuncheon and June 10 in Jeongup in 2013. At maturity, two central rows of each plot were harvested to determine seed yield, fatty acid composition, and oil and protein concentrations. Ten randomly selected plants per plot were used to measure plant height, number of branches per plant, number of nodes per plant, weight of 100 beans, and number of pods per plant. Additionally, qualitative traits such as growth habit, flower color, pubescence color, seed coat color, and hilum color were evaluated during yield trials.

\section{Determination of protein, oil, and fatty acid concentrations}

The soybeans produced at the three locations in 2013 were used to determine protein, oil, and fatty acid concentrations (Kim et al. 2015). The crude protein concentration in the soybeans was determined using the Kjeldahl method (AOAC 2011). Crude oil concentration was determined using $2 \mathrm{~g}$ of soybean flour using an automated Soxhlet extractor (Soxtherm, Gerhardt, Germany) according to the AOAC method (AOAC 2011). The solvent used for the crude oil extraction was n-hexane. The fatty acid profile of total oils for soybeans of each cultivar from each plot was analyzed using gas chromatography. Five seeds from each plot were randomly selected, and used for fatty acid analysis. Fatty acid concentration was expressed as the relative percentage of total oil content in each sample determined by gas chromatography (Agilent 7890A, Agilent, Palo Alto, CA).

\section{Data analysis}

Mean differences were determined using Fisher's Least Significant Difference (LSD) test, and coefficients of variation $(\mathrm{CV})$ were analyzed to compare stability among cultivars across different locations. All statistical analyses involved in this study were conducted using SAS 9.2.

\section{RESULTS}

The Hosim exhibited determinate growth, habit with white flowers and tawny pubescence at maturity. Seeds were yellow with gray hila (Table 1).

The agronomic characteristics and yield of Hosim and the two control cultivars, Taekwang and Uram, evaluated in 2012 are shown in Supplementary Table S1. Hosim (99 $\mathrm{cm}$ ) was significantly taller than Taekwang and Uram (76 and $82 \mathrm{~cm}$, respectively). The average number of branches of Hosim was 3.3, which was significantly lower than that of Taekwang and Uram (5.7 and 6.1, respectively). The average number of nodes of Hosim was 18.4, which was

Table 1. Qualitative traits of cultivar Hosim and Uram (check cultivar).

\begin{tabular}{ccccccc}
\hline \hline Cultivar & Growth habit & Flower color & Pubescence color & Seed coat color & Hilum color \\
\hline Hosim & Determinate & White & Tawny & Yellow & Gray \\
Uram & Determinate & White & Gray & Yellow & Yellow \\
\hline
\end{tabular}


significantly higher than that of Uram (15.7), although not significantly different from that of Taekwang (17.7). The weight of 100-seed of Hosim (16.9 g) was significantly lower than that of Taekwang (25.5 g) and Uram (24.1 g). However, there was no significant difference in yield, whose range was 2.84-3.20 t/ha, among the three soybean cultivars.

In 2013, the yield, yield-related traits, and protein, oil, and fatty acid concentrations of Hosim, Daewon, and Uram cultivated in Chuncheon, Gunwi, and Jeongup were evaluated (Supplementary Tables S2 and S3). No significant difference was observed in the yield of the cultivars grown in any of the three locations. The cultivars in all the locations combined were highly similar in average yield, i.e. 3.27, 3.18, and 3.16 t/ha for Hosim, Daewon, and Uram, respectively (Supplementary Table S2). Similar results were obtained by Carver et al. (1986) and La et al. (2014), who reported that increased oleic acid concentration in soybeans did not affect yield. Furthermore, there were no significant differences in plant height and numbers of branches, nodes, and pods among the three cultivars across the analyzed locations (Supplementary Tables S2). However, the mean weight of 100 seeds, 15.5, 21.8, and $23.8 \mathrm{~g} / 100$ seeds for Hosim, Daewon, and Uram, respectively, was observed to be significantly different.

In 2016, Hosim, along with Taekwang and Uram as controls, were cultivated in Gunwi, Korea to evaluate their agronomic traits. No significant differences were observed in plant height, number of branches per plant, maturity, and yield of Hosim, Taekwang, and Uram. The numbers of nodes and pods per plant and weight of 100 beans of Hosim were observed to be significantly different from those of Taekwang, although not from those of Uram (Table 2).

The average protein concentration in Hosim (40.3\%) was not significantly different from that in Daewon (39.2\%) and Uram (39.3\%), cultivated in the three Korean locations in 2013 (Supplementary Table S3). Contrastingly, the average oil content in Hosim (15.4\%) was significantly lower than that in Daewon (17.2\%) and Uram (17.0\%). Hosim had significantly lower concentrations of palmitic and stearic acids ( $7.5 \%$ and $3.1 \%$, respectively) than the two control cultivars, Daewon and Uram, with average palmitic acid concentrations of $10.3 \%$ and $10.9 \%$, respectively, and average stearic acid concentrations of $3.4 \%$ and $3.6 \%$, respectively. Regarding unsaturated fatty acids, Hosim had a significantly higher oleic acid concentration (79\%) than Daewon and Uram (22.7\% and $27.4 \%$, respectively). The linoleic acid concentration in Hosim (4.2\%) was significantly lower than that in Daewon (55.2\%) and Uram (49.8\%). Similarly, the linolenic acid concentration in Hosim was $6.2 \%$, which was significantly lower than that in Daewon and Uram $(8.5 \%$ and $8.3 \%$, respectively).

Moreover, the fatty acid profiling of Hosim, Taekwang, and Uram cultivated in 2016 in Gunwi, Korea was performed. The palmitic acid concentration in Hosim was observed to be $7.6 \%$, which was significantly different from that in Taekwang (9.2\%) and Uram (10.4\%). However, the stearic acid concentration in Hosim (2.9\%) was similar to that in Taekwang (2.9\%); however, it was significantly different from that in Uram (3.3\%) (Table 3). Concerning unsaturated fatty acids, the oleic acid concentration in Hosim was $78.9 \%$, which was significantly different from that of the two control cultivars, Taekwang $(43.5 \%)$ and Uram (34.8\%). As expected, the increase in oleic acid concentration was observed to occur at the expense of linoleic acid concentration, which was determined to be $4.5 \%$ in Hosim, relative to $38.5 \%$ in

Table 2. Agronomic characteristics and seed yields of a high oleic acid cultivar Hosim and commercial cultivars Taekwang and Uram at Gunwi, Korea, in 2016.

\begin{tabular}{lccccccc}
\hline \hline Genotype & $\begin{array}{c}\text { Plant height } \\
(\mathrm{cm})\end{array}$ & $\begin{array}{c}\text { Number of } \\
\text { branches/plant }\end{array}$ & $\begin{array}{c}\text { Number of } \\
\text { nodes/plant }\end{array}$ & $\begin{array}{c}\text { Number of } \\
\text { pods/plant }\end{array}$ & $\begin{array}{c}\text { 100-seed } \\
\text { weight }(\mathrm{g})\end{array}$ & $\begin{array}{c}\text { Maturity } \\
(\text { days })\end{array}$ & $\begin{array}{c}\text { Yield } \\
(\mathrm{t} / \mathrm{ha})\end{array}$ \\
\hline Hosim & 62.6 & 4.2 & 14.5 & 61.4 & 13.3 & 126 & 3.48 \\
Taekwang & 55.3 & 4.7 & 12.2 & 38.8 & 24.7 & 129 & 3.55 \\
Uram & 63.1 & 4.7 & 14.6 & 51.0 & 22.5 & 131 & 3.42 \\
LSD (5\%) & 13.4 & 1.4 & 1.8 & 17.0 & 2.2 & 0.77 \\
\hline
\end{tabular}


Table 3. The fatty acid composition of the high oleic acid cultivar Hosim compared with commercial cultivars Taekwang and Uram at Gunwi, Korea, in 2016.

\begin{tabular}{lccccc}
\hline \multirow{2}{*}{ Genotype } & \multicolumn{5}{c}{ Fatty acids concentration (\%) } \\
\cline { 2 - 6 } & Palmitic acid & Stearic acid & Oleic acid & Linoleic acid & Linolenic acid \\
\hline Hosim & 7.6 & 2.9 & 78.9 & 4.5 & 6.2 \\
Taekwang & 9.2 & 2.9 & 43.5 & 38.5 & 6.2 \\
Uram & 10.4 & 3.3 & 34.8 & 43.8 & 7.7 \\
LSD (5\%) & 0.5 & 0.1 & 3.2 & 2.5 & 0.2 \\
\hline
\end{tabular}

Taekwang and $43.8 \%$ in Uram (Table 3). Similar to stearic acid concentration, the linolenic acid concentration in Hosim (6.2\%) was similar to that in Taekwang (6.2\%), yet significantly different from that in Uram (7.7\%).

The fatty acid profiling results suggested that Hosim had a high oleic acid concentration across locations, and the concentration was highly stable (Lee et al. 2012). Since oil from Hosim soybeans was high in oleic acid and low in linoleic acid, its inclusion in daily diets could provide greater benefits to human health than oil from Daewon and Uram soybeans.

\section{DISCUSSION}

High oleic acid concentration is a desirable characteristic in soybean breeding, because of the health benefits of oleic acid. In this study, we evaluated the performance of agronomic traits of the high-oleic acid cultivar, Hosim, developed by combining mutant alleles with single-base pair variation at the FAD2 locus (Kim et al. 2015). The contents of oil, as well as those of palmitic, linoleic, and linolenic acids were low in Hosim. The increases in oleic acid concentration were observed to be largely at the expense of linoleic and linolenic acid concentrations. Significant negative correlations between oleic acid concentrations and polyunsaturated fatty acid concentrations have been reported in a few previous studies (Bachlava et al. 2008; La et al. 2014; Kulkarni et al. 2017).

While modifying the fatty acid profile, it is necessary to consider possible changes in agronomic traits, especially negative effects on seed yield. Many studies have shown that temperature fluctuations, seasonal variations, and different geographical locations might influence the fatty acid composition in soybean plants (Scherder and Fehr 2008; Primomo et al. 2002; Bachlava et al. 2008; La et al. 2014). The yield of Hosim was observed to be stable across locations, and was not affected by increases in oleic acid concentrations. Moreover, the field performance of other important related agronomic traits of Hosim was similar across the evaluated locations. Hence, Hosim could be an important genetic resource in crop improvement programs aimed at increasing oleic acid concentration without negatively affecting yield. Furthermore, soy-based foods, such as chungkookjang, natto, soybean paste, soy sauce, tofu, and soybean sprouts, prepared using Hosim soybeans may provide benefits to human health. In addition to applications in the food industry, oil from Hosim soybeans has wide industrial applications.

\section{ACKNOWLEDGEMENTS}

This work was carried out with the support of "Cooperative Research Program for Agriculture Science \& Technology Development" (Project No. PJ907034), "Rural Development Administration”, Republic of Korea.

\section{REFERENCES}

Ascherio A, Willett WC. 1997. Health effects of trans fatty acids. Am J. Clin. Nutr. 66: 1006-1010.

AOAC (Association of official analytical chemists). 2011. Official methods of analysis, 18th edn. AOAC, Gaithersburg.

Bachlava E, Burton JW, Brownie C, Wang S, Auclair J, Cardinal AJ. 2008. Heritability of oleic acid content in 
soybean seed oil and its genetic correlation with fatty acid and agronomic traits. Crop Sci. 48: 1764-1772.

Bahrami G. 2009. Trans and other fatty acids: effects on endothelial functions. p. 3-43. In: R. Watson (ed.). Fatty acids in health promotion and disease causation. AOCS Press, Urbana.

Burton JW, Wilson RF, Rebetzke GJ, Pantalone VR. 2006. Registration of N98-4445A mid-oleic soybean germplasm line. Crop Sci. 46: 1010-1012.

Carrillo C, Cavia MD, Alonso-Torre S. 2012. Role of oleic acid in immune system; mechanism of action; a review. Nutr. Hosp. 27: 978-980.

Carver BF, Burton JW, Carter TE Jr, Wilson RF. 1986. Response to environmental variation of soybean lines selected for altered unsaturated fatty acid composition. Crop Sci. 26: 1176-1181.

Dierking EC, Bilyeu KD. 2009. New sources of soybean seed meal and oil composition traits identified through TILLING. BMC Plant Biol. 9: 89.

Hoshino T, Takagi Y, Anai T. 2010. Novel GmFAD2-1B mutant alleles created by reverse genetics induce marked elevation of oleic acid content in soybean seeds in combination with GmFAD2-1A mutant alleles. Breed. Sci. 60: 419-425.

Kim HJ, Ha BK, Ha KS, Chae JH, Park JH, Kim MS, et al. 2015. Comparison of a high oleic acid soybean line to cultivated cultivars for seed yield, protein and oil concentrations. Euphytica 201: 285-292.

Ko JM, Han WY, Kim HT, Lee YH, Choi MS, Lee BW, et al. 2016. Soybean cultivar for soy-paste, 'Uram' with mechanization harvesting, large seed, disease resistance and high yield. Korean J. Breed. Sci. 48: 301-306.

Kulkarni KP, Kim M, Song JT, Bilyeu KD, Lee JD. 2017. Genetic improvement of the fatty acid biosynthesis system to alter the $\omega-6 / \omega-3$ ratio in the soybean seed. J. Am. Oil. Chem. Soc. 94: 1403-1410.

Lee JD, Bilyeu KB, Pantalone VR, Gillen AM, So YS, Shannon JG. 2012. Environmental stability of oleic acid concentration in seed oil for soybean lines with FAD2-1A and FAD2-1B mutant genes. Crop Sci. 52: 1290-1297.

Lee JD, Bilyeu KB, Shannon JG. 2007. Genetics and breeding for modified fatty acid profile in soybean seed oil. J. Crop Sci. Biotech. 10: 201-210.

Lee JD, Bilyeu KD, Pantalone VR, Gillen AM, So YS, Shannon JG. 2012. Environmental stability of oleic acid concentration in seed oil for soybean lines with FAD2-1A and FAD2-1B mutant genes. Crop Sci. 52: 1290-1297.

Monteros MJ, Burton JW, Boerma H. 2008. Molecular mapping and confirmation of QTLs associated with oleic acid content in N00-3350 soybean. Crop Sci. 48: 2223-2234

Pham AT, Lee JD, Shannon JG, Bilyeu KD. 2011. A novel $F A D 2-1 A$ allele in a soybean plant introduction offers an alternate means to produce soybean seed oil with $85 \%$ oleic acid content. Theor. Appl. Genet. 123: 793-802.

Pham AT, Lee JD, Shannon JG. Bilyeu KD. 2010. Mutant alleles of FAD2-1A and FAD2-1B combine to produce soybeans with the high oleic acid seed oil trait. BMC Plant Biol. 10: 195.

Primomo VS, Falk DE, Ablett GR, Tanner JW, Rajcan I. 2002. Genotype $x$ environment interactions, stability, and agronomic performance of soybean with altered fatty acid profiles. Crop Sci. 42: 37-44.

Rahman MS, Takagi Y, Kubota K, Miyamoto K, Kawakita T. 1994. High oleic acid mutant in soybean induced by X-Ray irradiation. Biosci. Biotechnol. Biochem. 58: 1070-1072.

Sales-Campos H, Reis de Souza P, Crema Peghini B, Santana da Silva J, Ribeiro Cardoso C. 2013. An overview of the modulatory effects of oleic acid in health and disease. Mini-Rev. Med. Chem. 13: 201-210.

Scherder CW, Fehr WR. 2008. Agronomic and seed characteristics of soybean lines with increased oleate content. Crop Sci. 48: 1755-1758.

Scherder CW, Fehr WR, Shannon JG. 2008. Stability of oleate content in soybean lines derived from M23. Crop Sci. 48: 1749-1754.

Teres S, Barcelo-Coblijn G, Benet M, Alvarez R, Bressani R, Halver JE, et al. 2008. Oleic acid content is responsible for the reduction in blood pressure induced by olive oil. Proc. Natl. Acad. Sci. U.S.A. 105: 13811-13816.

La TC, Safiullah MP, Voung T, Lee JD, Scaboo AM, Smith JR, et al. 2014. Effect of high-oleic acid soybean on seed oil, protein concentration, and yield. Crop Sci. 54: 2054-2062.

Williams CM. 2001. Beneficial nutritional properties of olive oil: implications for postprandial lipoproteins and factor VII. Nutr. Metab. Cardiovasc. Dis. 11: 51-56.

Wilson RF. 2004. Seed composition. P. 621-677. In: Boerma HR, Specht JE (eds.). Soybeans: improvement, production, 
and uses, 3rd ed. American Society of Agronomy-Crop Science Society of America-Soil Science Society of America, Madison, WI.
Wilson RF, Burton JW, Brim CA. 1981. Progress in the selection for altered fatty acid composition in soybeans. Crop Sci. 21: 788-791. 